\title{
Structural analysis of the eruptive fissures at Mount Etna (Italy)
}

\author{
Marco Neri ${ }^{1{ }^{\star}}{ }^{\star}$, Valerio Acocella ${ }^{2}$, Boris Behncke ${ }^{1}$, Salvatore Giammanco ${ }^{1}$, \\ Francesco Mazzarini ${ }^{3}$, Derek Rust ${ }^{4}$ \\ ${ }^{1}$ Istituto Nazionale di Geofisica e Vulcanologia, Sezione di Catania, Osservatorio Etneo, Catania, Italy \\ ${ }^{2}$ Università Roma Tre, Dipartimento di Scienze Geologiche, Rome, Italy \\ ${ }^{3}$ Istituto Nazionale di Geofisica e Vulcanologia, Sezione di Pisa, Pisa, Italy \\ ${ }^{4}$ University of Portsmouth, School of Earth and Environmental Sciences, Portsmouth, United Kingdom
}

\author{
Article history \\ Received November 26, 2010; accepted April 30, 2011. \\ Subject classification: \\ Eruptive fracture, Dike, Magmas, Tectonics, Structural geology.
}

\section{ABSTRACT}

Mount Etna produces frequent eruptions from its summit craters and from fissures on its flanks. The flank fissures trend approximately radially to the summit, and are mainly concentrated in three rift zones that are located on the NE, S and W flanks. Many flank eruptions result from lateral magma transfer from the central conduit into fractures intersecting the flanks, although some eruptions are fed through newly formed conduits that are not directly linked to the central conduit. We analyzed the structural features of eruptions from 1900 to the present, one of the most active periods in the documented eruptive history of Etna, which comprised 35 summit and 33 flank events. Except for a small eruption on the W flank in 1974, all of the flank eruptions in this interval occurred on or near the NE and $S$ rifts. Eruptions in the NE sector were generally shorter, but their fissure systems developed more rapidly and were longer than those in the S sector. In contrast, summit eruptions had longer mean durations, but generally lower effusion rates (excluding paroxysmal events characterized by very high effusion rates that lasted only a few hours). This database was examined considering the main parameters (frequency and strike) of the eruptive fissures that were active over the last $\sim 2 \mathrm{ka}$. The distribution in time and space of summit and flank eruptions appears to be closely linked to the dynamics of the unstable E to S flank sector of Etna, which is undergoing periodic displacements induced by subvolcanic magma accumulation and gravitational pull. In this framework, magma accumulation below Etna exerts pressure against the unbuttressed $E$ and $S$ flanks, which have moved away from the rest of the volcano. This has caused an extension to the detachment zones, and has facilitated magma transfer from the central conduit into the flanks.

\section{Introduction}

Mount Etna (Italy) is one of the most active volcanoes on Earth. Although it is nearly continuous, the summit activity does not pose a significant threat to human life and property. On the contrary, flank eruptions represent the most dangerous type of eruptive activity, since these occur closer to vulnerable areas, such as towns, villages, lifelines, and cultivated land [Crisci et al. 2010].

Etna is located at the edge of the Appenine-Maghrebian Chain [Cristofolini et al. 1979, Lanzafame et al. 1997], along the N-S trending extensional Malta escarpment (Figure 1, inset), and it lies on Pliocene-Pleistocene foredeep deposits [Lentini 1982]. Its tectonic setting is characterized by an overall E-W extension direction [Bousquet and Lanzafame 1986, Monaco and Tortorici 2000]. Volcanism at Etna evolved from sporadic, predominantly subaerial and submarine, activity along fissures (up to $200 \mathrm{ka}$ ago), with the development of several vents that are dispersed over a wide area. Finally (200 ka ago - today) there was the construction of the present-day stratovolcano [Romano and Sturiale 1982, Corsaro et al. 2002, Tanguy et al. 2003, Branca et al. 2004].

Central stratovolcanoes like Etna are often characterized by summit and flank eruptions. Summit eruptions are the consequence of the ascent of magma from a reservoir through a central conduit. Flank eruptions are commonly characterized by multiple aligned vents that radiate from the summit of the volcano. Most of the observed flank eruptions at Etna originated from the central conduit: here, while the magma rises to often feed summit eruptions, at times it propagates laterally and downslope, to feed radial fissures and flank eruptions [i.e. Rubin and Pollard 1987]. Sometimes, flank eruptions are not fed through the central conduit, but they are directly fed through new conduits from a reservoir beneath the volcano [Acocella and Neri 2003, and references therein].

In this report, we illustrate the modalities of the flank eruptions at Etna over approximately the last 2000 years, with particular attention to the last 110 years of activity, for which a detailed structural database is shown and discussed. 


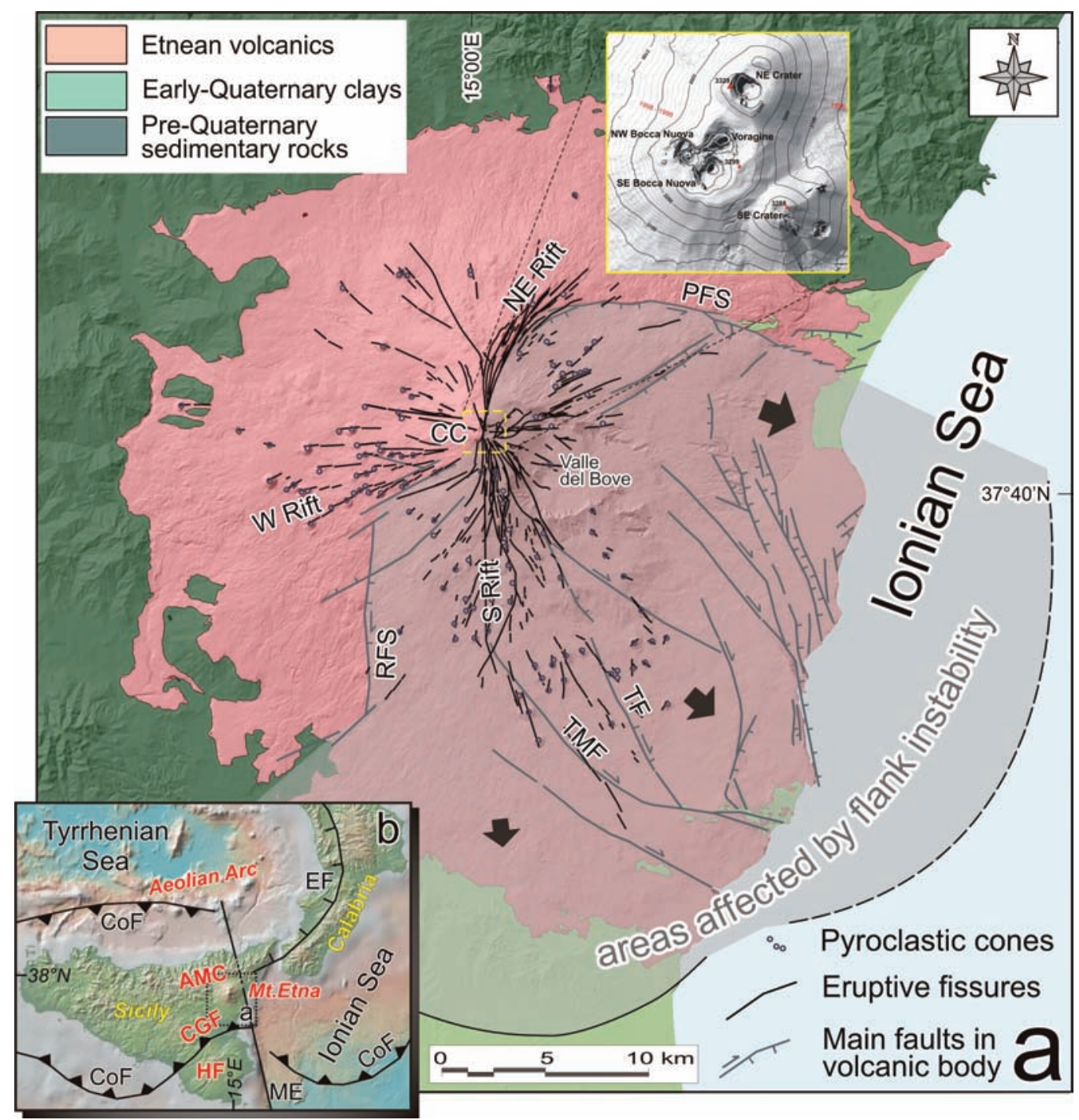

Figure 1. Simplified structural map of Mount Etna (a), showing the distribution of Etnean volcanics, eruptive fissures and major pyroclastic cones produced by flank eruptions, significant fault systems, and the sector of the volcano that is affected by flank instability-induced displacement. Arrows indicate directions of movement for different portions of the mobile flank sector. Inset at top: LIDAR-derived digital elevation model of the summit crater complex [Neri et al. 2008b]. CC, central craters; PFS, Pernicana fault system; RFS, Ragalna fault system; TF, Trecastagni fault; TMF, Tremestieri fault. The pre-Quaternary sedimentary rocks include the AMC and CGF deposits. The regional tectonic context is shown in inset (b); AMC, Appenine-Maghrebian Chain; CGF, Gela-Catania foredeep; HF, Hyblean foreland; ME, Malta Escarpment; CoF, compressional front; EF, extensional front; the area outlined by the broken line is the area enlarged in (a).

The main goal is the construction of an interpretative model of the transfer of magma within the volcanic edifice, to define the main structural parameters, and possibly, the role of the magmatic intrusions in the framework of the instability of the volcano flanks.

\section{Types and frequency of Mount Etna eruptions}

Mount Etna is the highest active volcano in Europe (at $3,329 \mathrm{~m}$ above sea level [asl] in summer 2007) [Neri et al. $2008 \mathrm{~b}$ ], and it has an open central conduit that feeds four summit craters that are located close to the $\mathrm{W}$ rim of the Valle del Bove depression: Voragine (VOR; active since 1945 inside the former central crater), the NE Crater (active since 1911), Bocca Nuova (BN; active since 1968), and the SE Crater (SEC; active since 1971) (Figure 1). The volcanic activity is mainly focused at the summit of the volcano, and it generates gas emissions, strombolian to paroxysmal (Hawaiian, violent Strombolian to sub-Plinian) activity, and lava overflows (Figure 2) from one of these summit craters, producing so-called "summit eruptions".

At times, the volcanic activity occurs along radial fissures that form flank eruptions from three main "rift zones" [Rittmann 1973, Corazzato and Tibaldi 2006]: the NE Rift, the S Rift and the W Rift (Figure 1). In these cases, magma moves upwards through the central conduit, and at shallow levels (a few hundreds of meters, up to 1-3 km) it propagates laterally, penetrating, in most cases, into the rift zones (Figure 3a). Thus, these eruptions are fed by the central conduit rather than directly from the magma reservoir [McGuire and Pullen 1989, Tanguy and Kieffer 1993, Bousquet and Lanzafame 2001]. This type of eruption was named as "central-lateral" by Acocella and Neri [2003] 


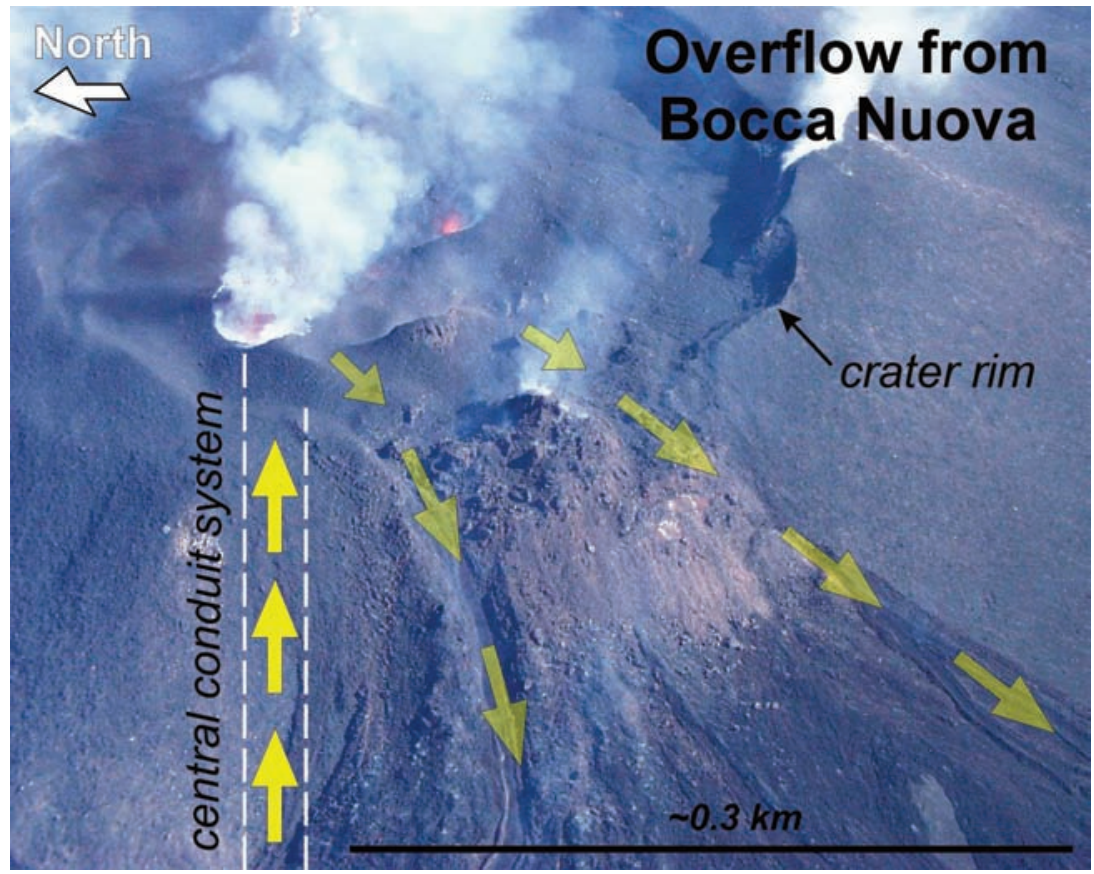

Figure 2. Aerial view of a typical lava overflow from one of the Etna summit craters, the Bocca Nuova, in October 1999. Such overflows are directly fed through the central conduit system, which leads up to the four summit craters of Etna.

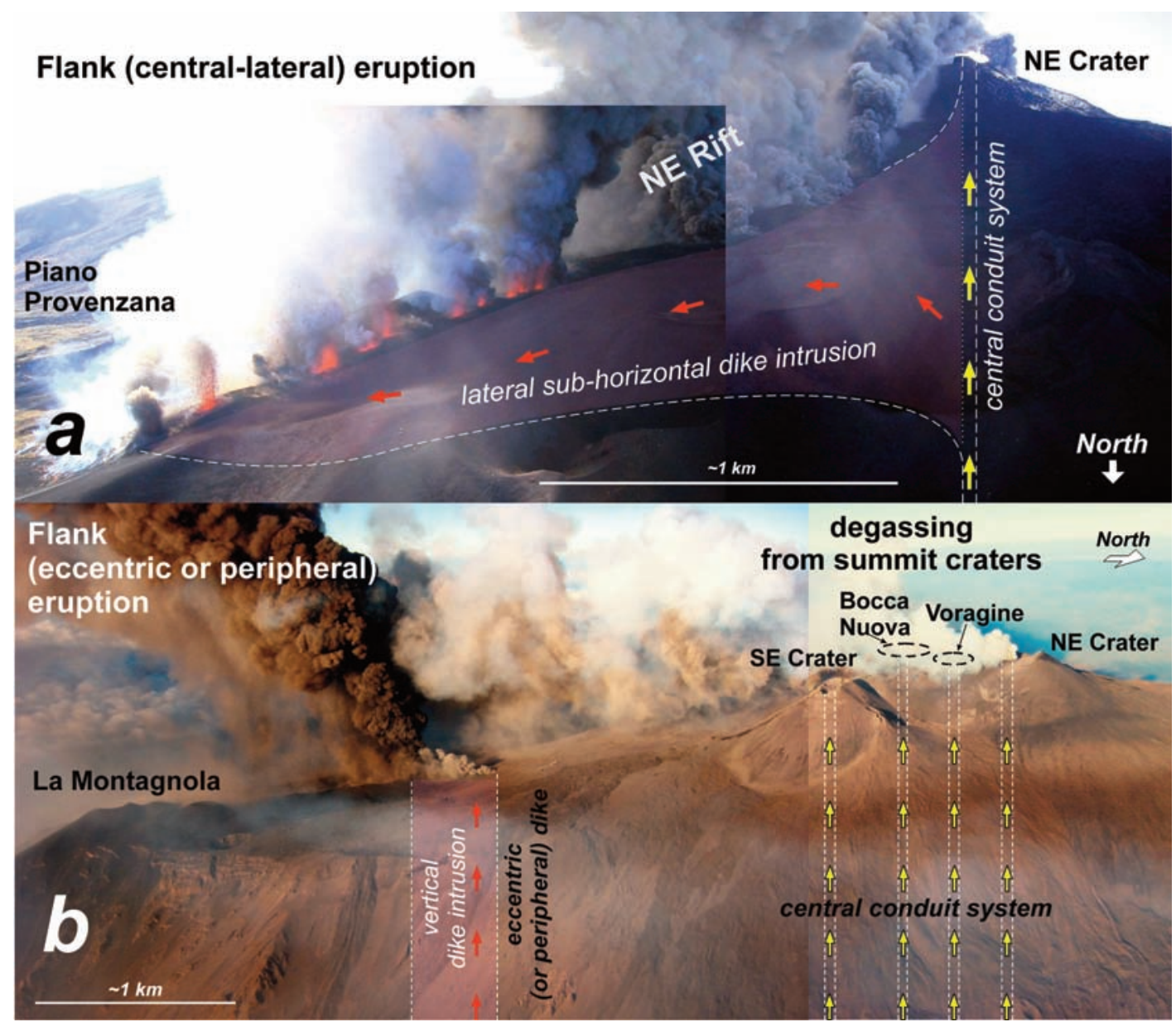

Figure 3. Conceptual model of the two types of flank eruptions at Etna, central-lateral (a) versus eccentric (or peripheral) (b), as illustrated by the two phases of the 2002-2003 eruption. (a) Lateral transfer of magma from the central conduit (the NE Crater) into the NE Rift leads to a typical central-lateral eruption, with numerous vents aligned along a downslope-propagating eruptive fissure system of more than $5 \mathrm{~km} \mathrm{long}$ (October 27 - November 5 , 2002). (b) Eruptive activity on the upper $\mathrm{S}$ flank is fed through a new, eccentric conduit, and restricted to a relatively short fissure with fewer vents. The activity here is characterized by much more enhanced explosivity compared to the central-lateral activity on the NE Rift (October 28, 2002 - January 28, 2003). Both central-lateral and eccentric activities occurred simultaneously during the 2001 and 2002-2003 eruptions. 


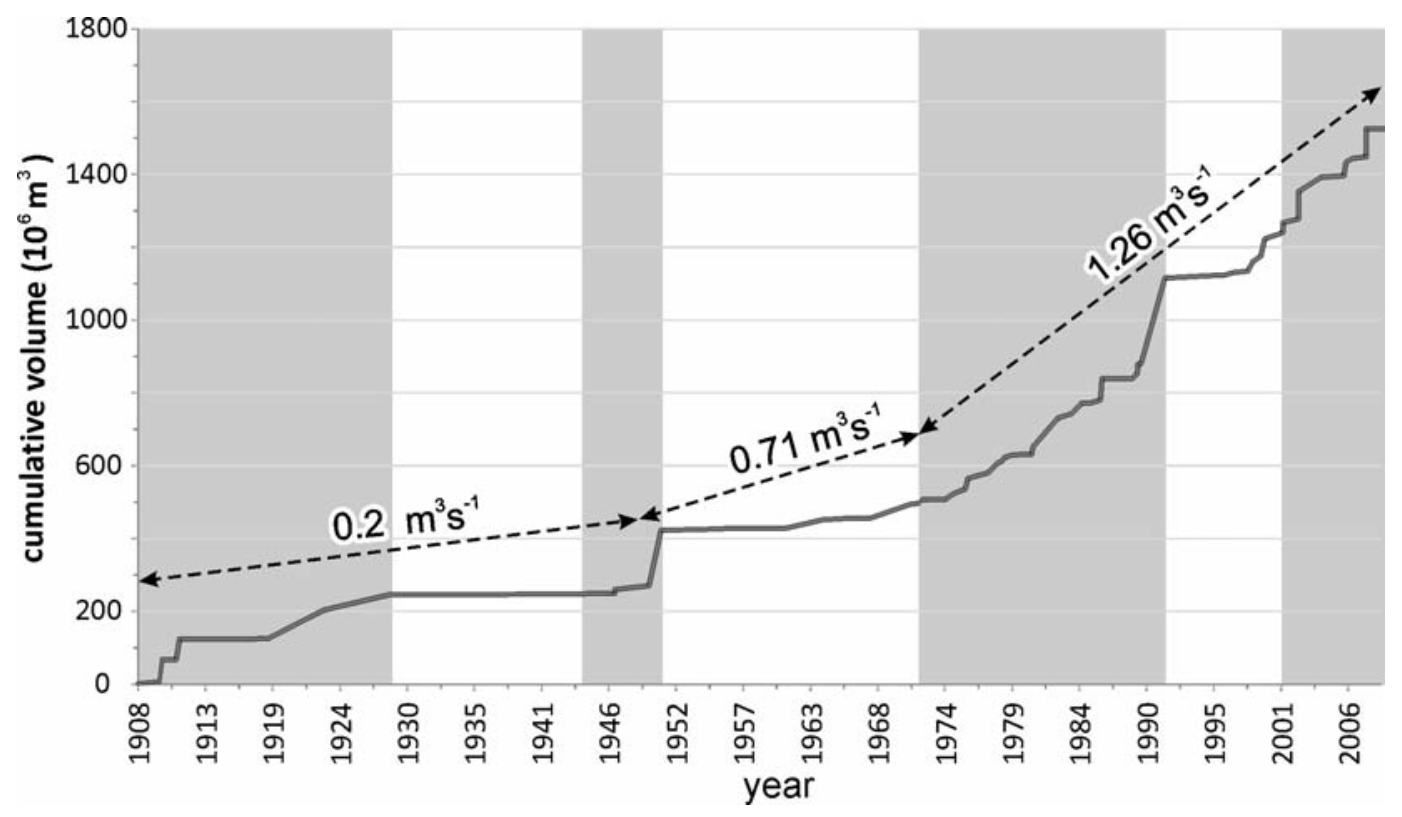

Figure 4. Cumulative magma output at Mount Etna from 1900 to 2010, showing how higher mean output rates and larger individual events are linked to periods when there are clusters of flank eruptions (marked with gray shading). These periods are also marked by enhanced movement of the unstable flank sectors [see Behncke and Neri 2003, Walter et al. 2005, Allard et al. 2006, Neri et al. 2004, Neri et al. 2009, Solaro et al. 2010]. Dashed arrows indicate three periods (1908-1949, 1950-1970, 1071-2010) that were characterized by different outputs (numbers on the arrows give the average eruption rate of each period).

and Neri et al. [2005]. The same mechanism of intrusion has been commonly observed at Hawaii [Holcomb 1987, Lockwood et al. 1987], Stromboli [Neri et al. 2008a], Vesuvius [Acocella et al. 2009, and references therein], Nyiragongo [Tedesco et al. 2007], Miyakejima [Geshi et al. 2002, 2010], Izu-Oshima [Sumner 1998], Taveuni [Cronin et al. 2001], Huaynaputina [Adams et al. 2001], and Piton de la Fournaise [McClelland et al. 1989, Peltier et al. 2008].

A few flank eruptions have been triggered by magmatic intrusions that are not fed through the central conduit, as shown by any lack of continuity between the flank eruptions and the summit craters of the volcano (in terms of seismicity, surface deformation, and petro-chemical data). These eruptions are possibly directly fed by the reservoir beneath the volcano, and they are here named as "eccentric" or "peripheral" eruptions [Rittman 1973, Acocella and Neri 2003] (Figure 3b). This type of eruption was first described for Lamongan volcano [Kemmerling 1922] and has also been observed at Miyakejima [McClelland et al. 1989] and Fernandina [Jonsson et al. 1999] volcanoes. Stress fields controlled by regional tectonics have been commonly invoked to explain the dynamics of the lateral flow of magma from reservoirs, and thus the occurrence of peripheral eruptions [Gudmundsson 1987, 1998]. Nevertheless, all of these mentioned peripheral eruptions, except for Lamongan, occurred within volcanic edifices at least 2,000 $\mathrm{m}$ high. This suggests that as an alternative to a regional component, peripheral volcanic activity can also be influenced by a component of stress due to the load of the volcano [Acocella and Neri 2009].

While the summit activity is close to continuous at Etna, flank eruptions (both central-lateral and eccentric) occur at irregular intervals, in a range of less than one year to several decades, and they appear to be organized in cycles. Indeed, Behncke and Neri [2003] suggested that the cycles occurred on two main time scales: in the long-term, and in the shortterm. A long-term cycle lasts several centuries and consists of three phases: a first phase characterized by low levels of activity, mainly at the summit, and two subsequent phases during which flank eruptions become more frequent and more voluminous, especially during the third culminative phase [Wadge et al. 1975 and Guest and Murray 1979].

Conversely, short-term eruptive cycles last several decades. In the recent history of Etna, short-term cycles have been common since 1865, and consist of three distinct phases: (a) a period of eruptive quiescence that lasts $<3.5$ years; (b) a period of more or less continuous summit activity that lasts from 6 to 16 years; and (c) a series of flank eruptions that often have intervening summit activity, and that extend from 9 to 22 years. The last eruptive cycle of Etna began after the 1991-1993 flank eruption, and it has developed into 8 years of progressively more frequent summit activity, followed by a series of flank and summit eruptions. There have been four important flank eruptions since 2001 (Figure 4) [Allard et al. 2006, Neri et al. 2009].

Here we review the eruptive history of the Etna volcano over the last 110 years, as organized into a database (Table 1). Furthermore, to expand the number of structural elements that can be analyzed as much as possible, we consider also the main parameters (frequency and strike) of the eruptive fissures up to $\sim 2 \mathrm{ka}$ BP that are still visible on the flanks of the volcano, or that have been covered by recent lava, but are 


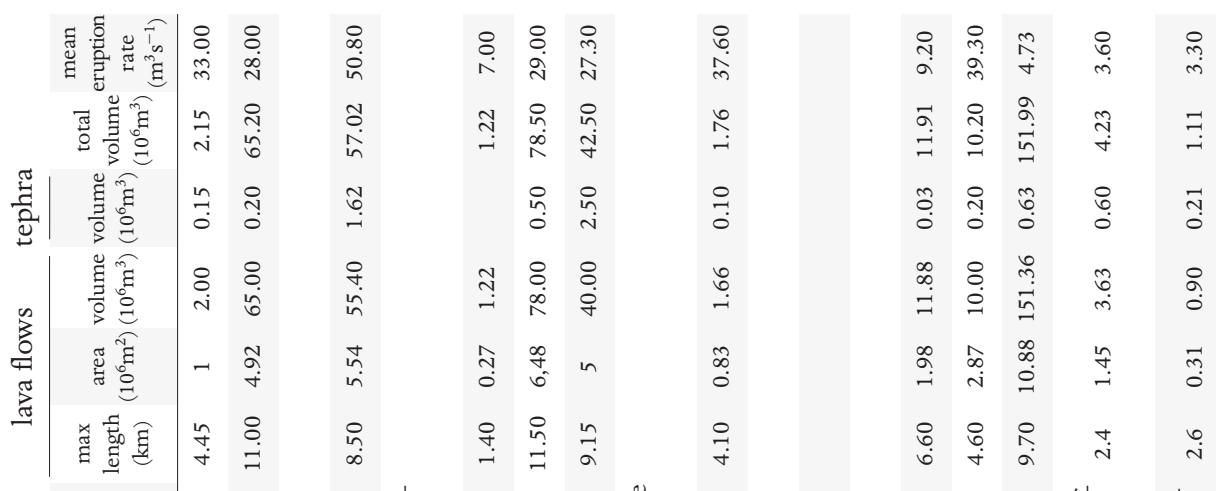

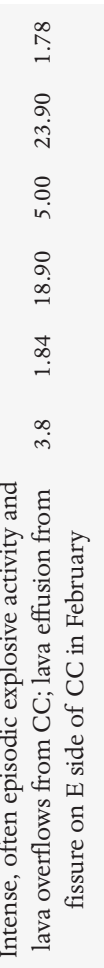

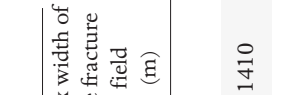

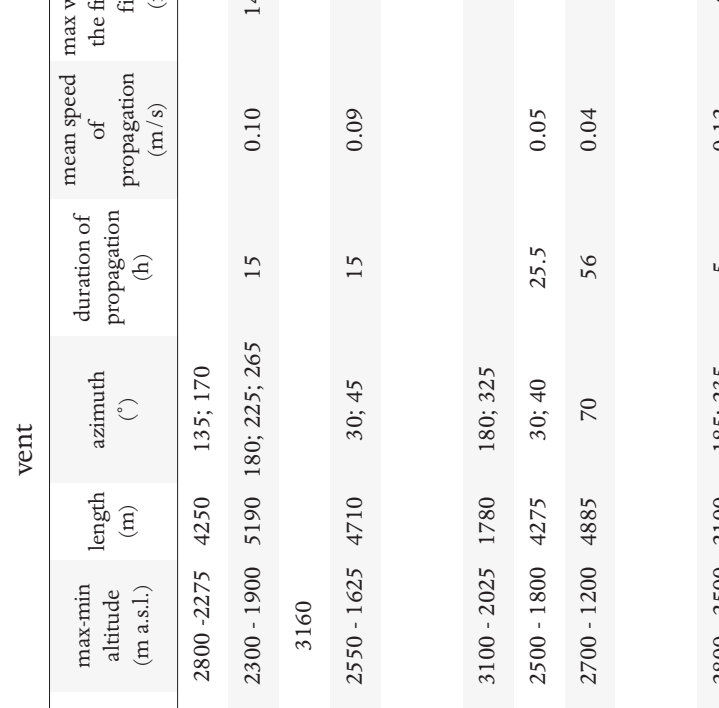

8

$\because$

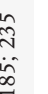

$\stackrel{4}{\circ}$

玄

㐫

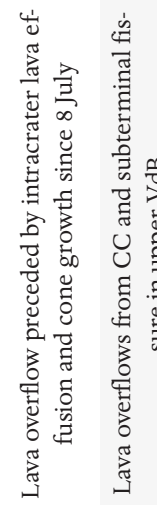

$\stackrel{8}{\square}$

$\stackrel{\infty}{0}: \stackrel{0}{0}$

$\simeq \simeq \sim$

q

î̀

î̀

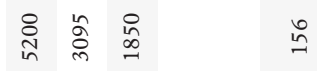

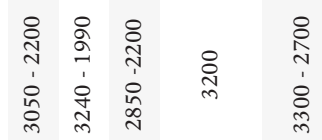

nิ

$\stackrel{\infty}{\sim}$

¿ั

율

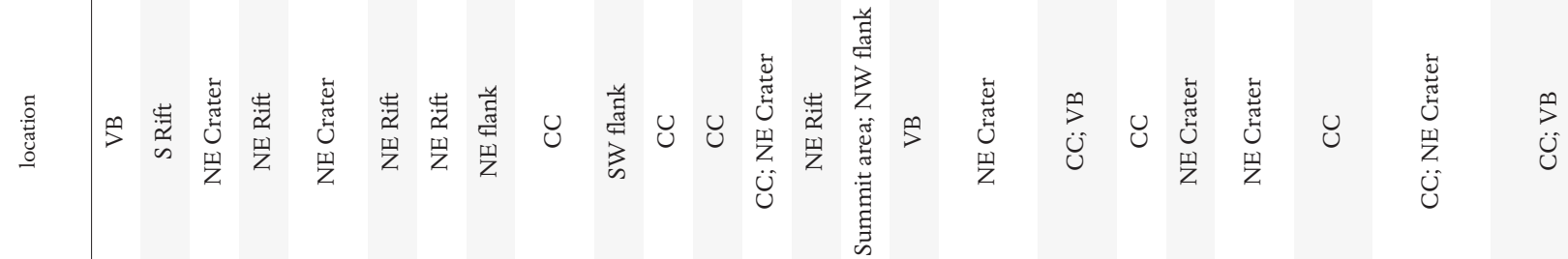

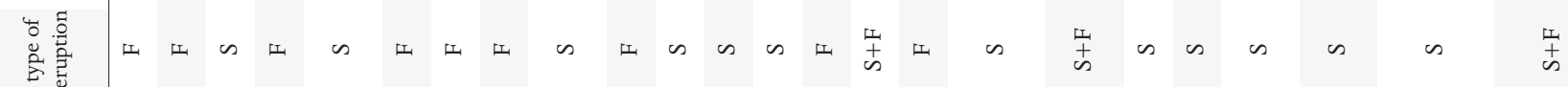

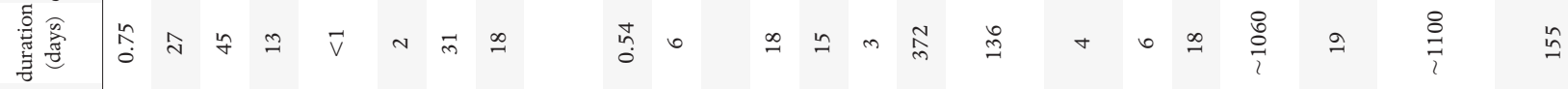

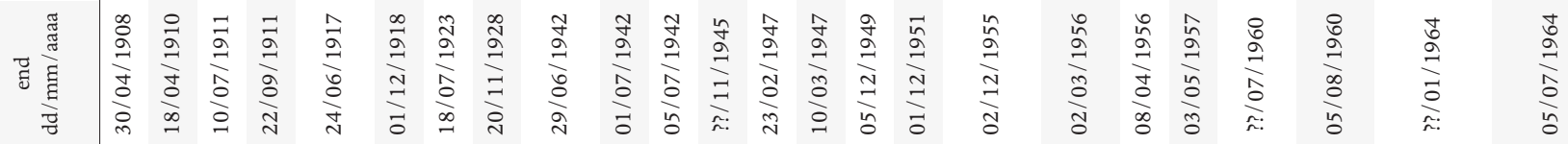

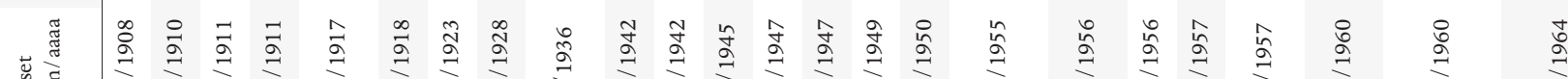

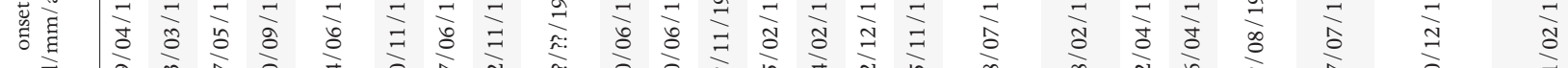

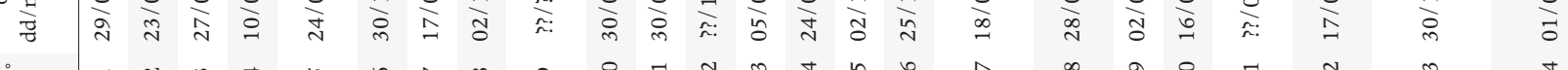




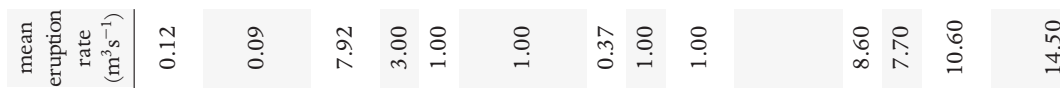

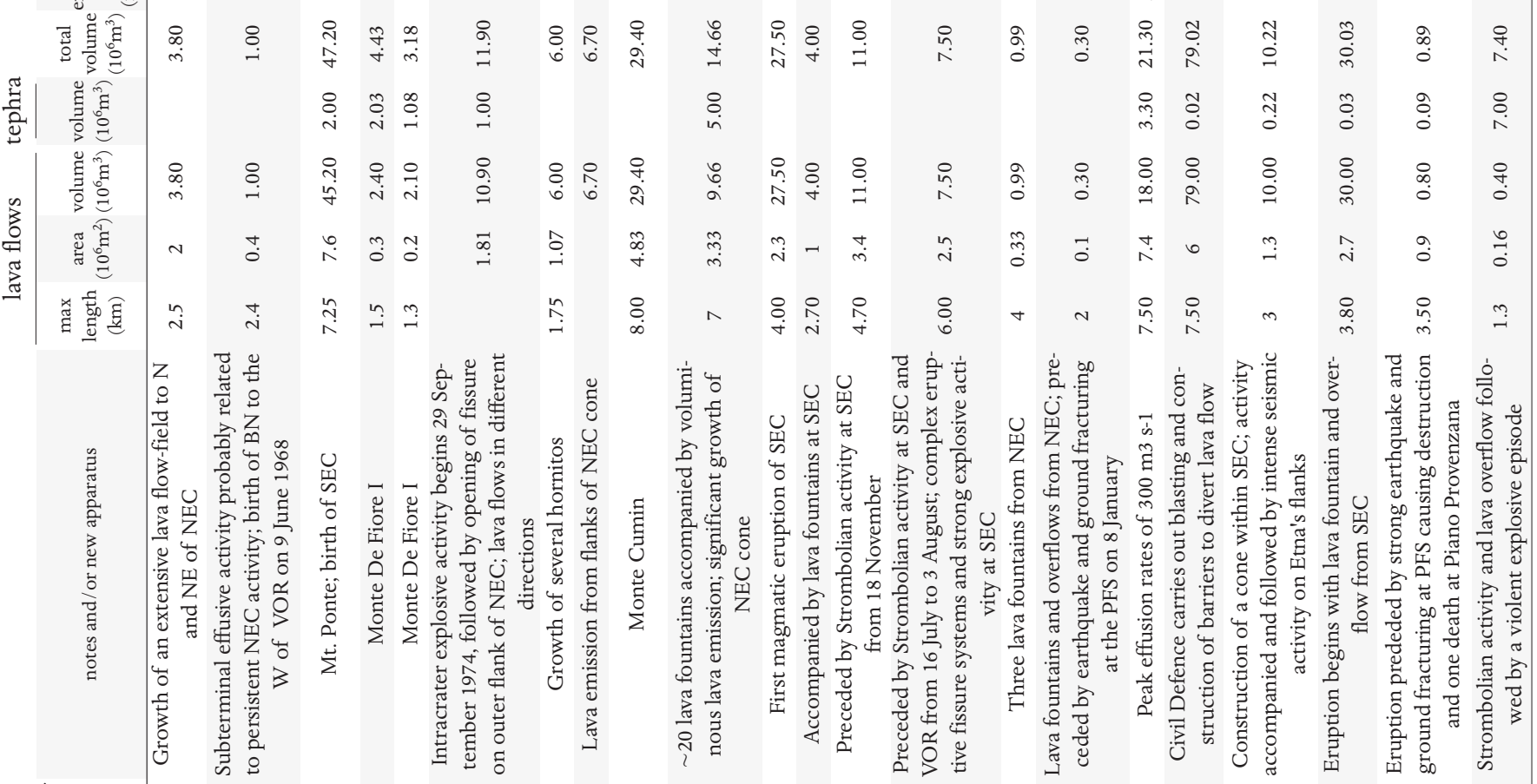

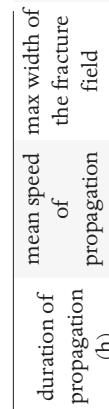

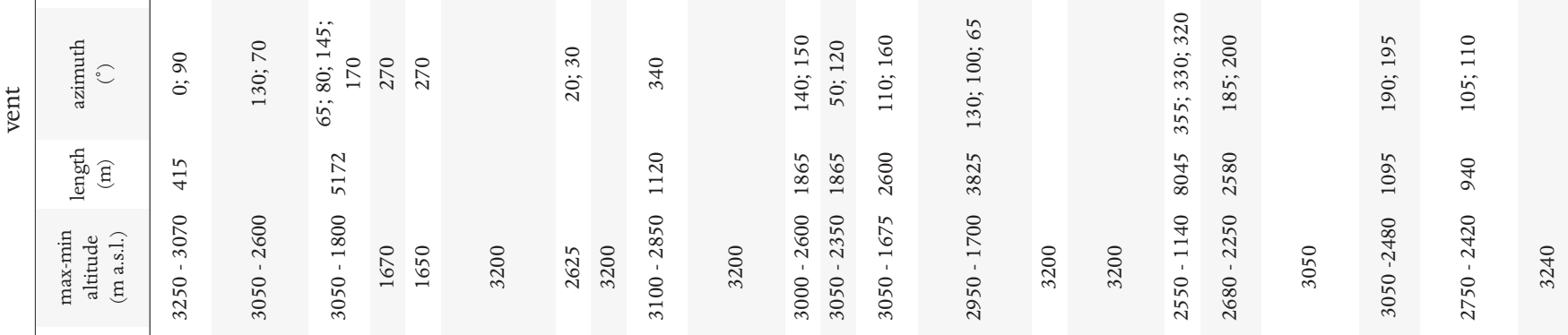

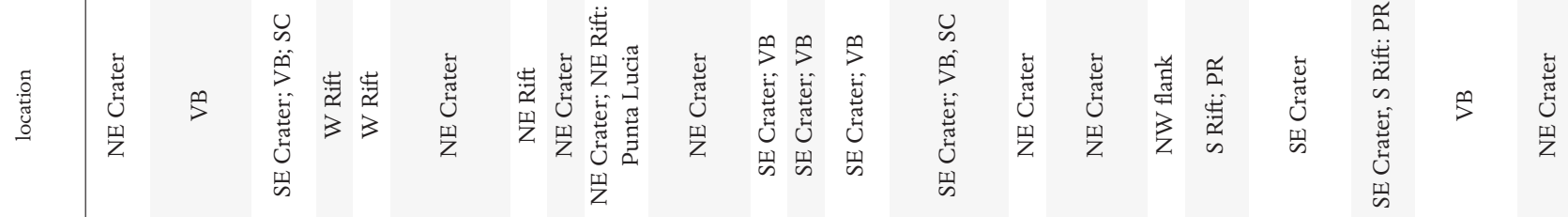

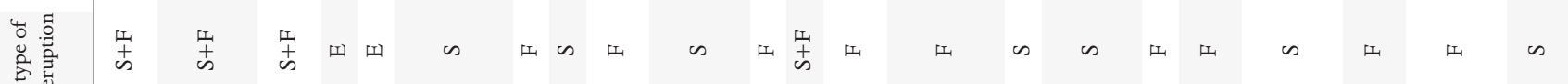

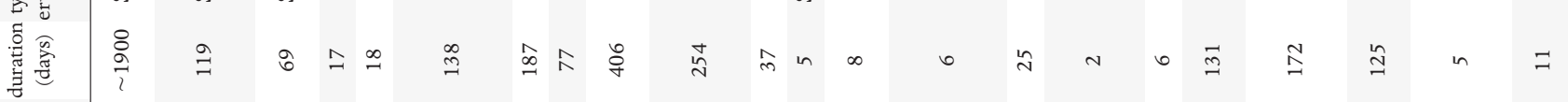

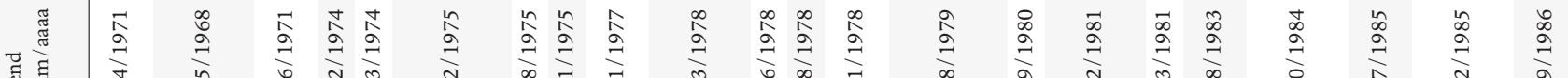

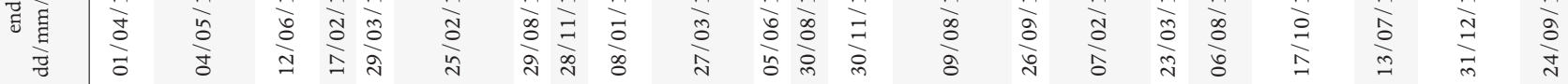

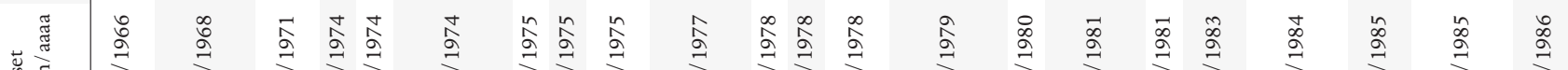
य)

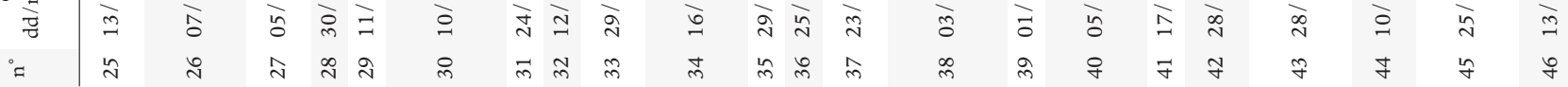




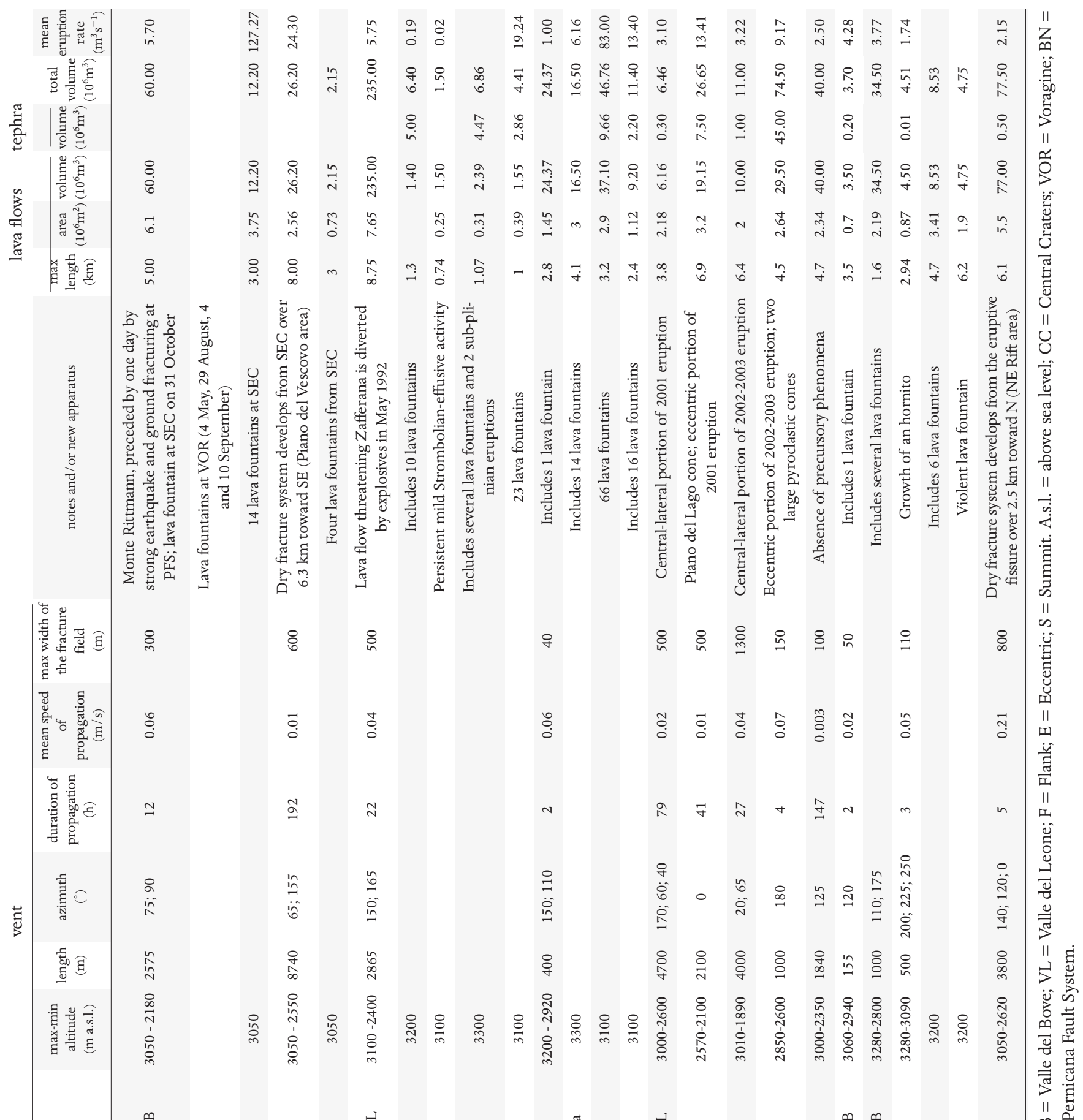

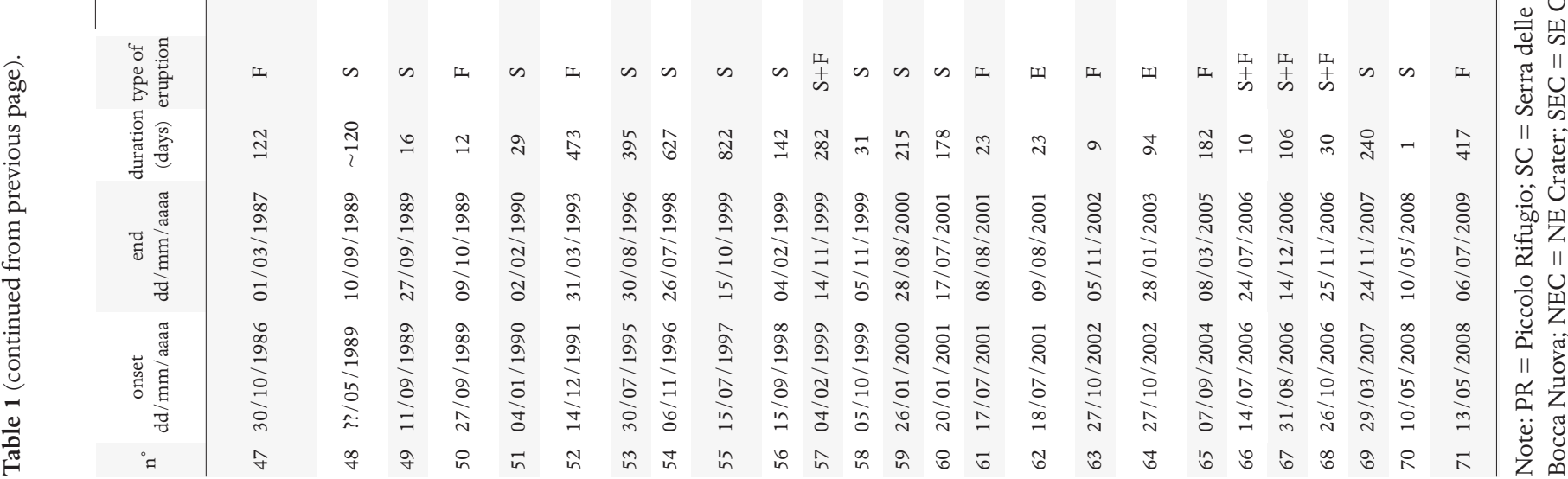



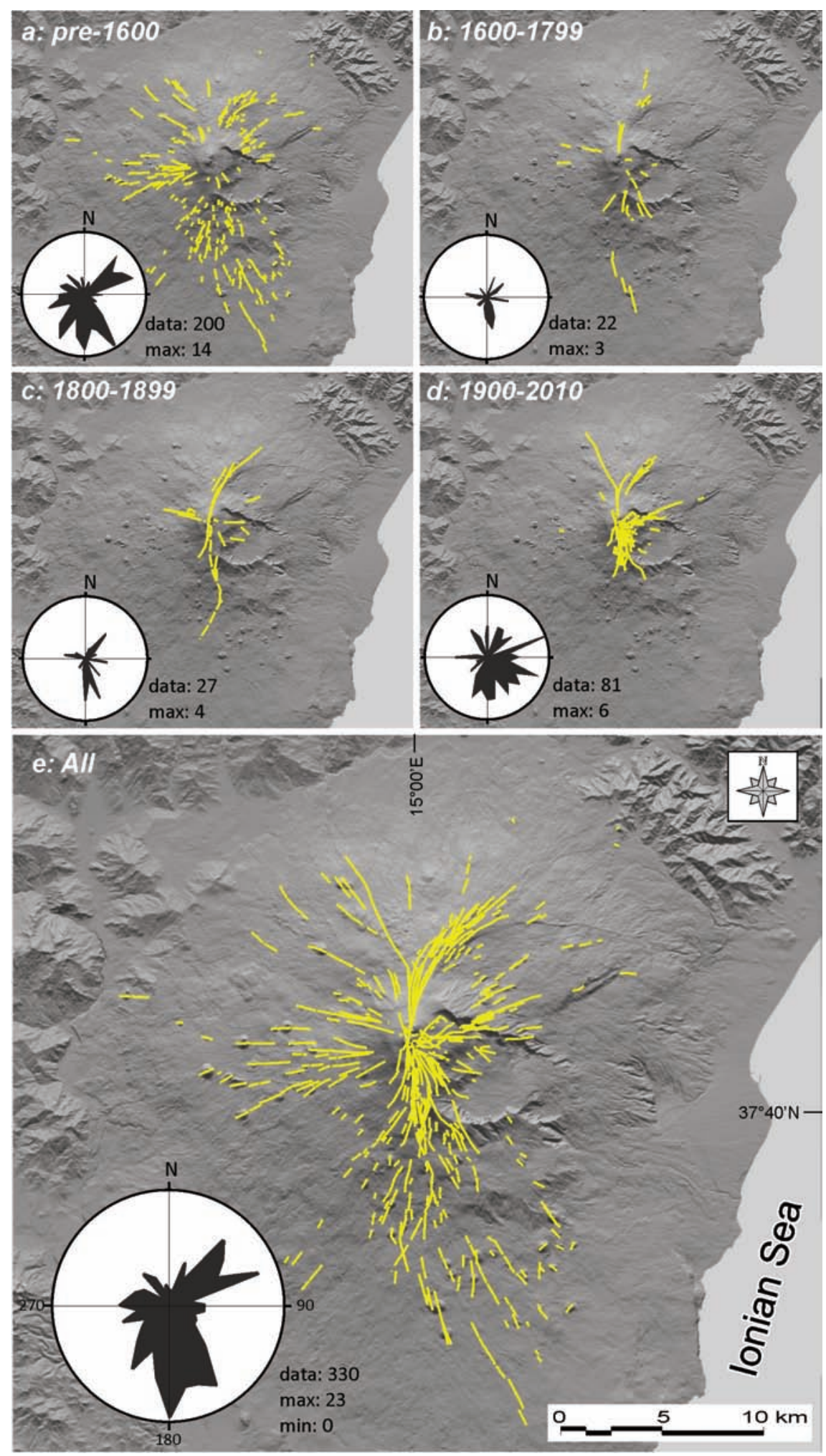

Figure 5. Historically active eruption fissures at Etna, grouped into periods: pre-1600 (a), $17^{\text {th }}$ and $18^{\text {th }}$ centuries (b), $19^{\text {th }}$ century (c), $1900-2010(d)$, and all of the fissures together (e).

known from the literature [Romano and Sturiale 1982, Behncke et al. 2005]. All of these eruptive fissures are mapped together to improve our understanding of the dynamics of the Etna summit and flank eruptions, to better evaluate the roles of tectonics and topography. Possible links with the structural instability that affects the volcano flanks are also analyzed.

\section{The eruptive fissures}

In the present study, we consider information on 330 eruptive fissures tha occurred over approximately the last $2 \mathrm{ka}$. The reliability of the sources on past eruptions at Etna can be considered adequate only from the beginning of the $17^{\text {th }}$ century [Behncke et al. 2005, Branca and Del Carlo 2005]. Fissures that formed before 1600 are usually quite uncertain 
in age. Therefore, here we refer to the pre-1600 fissures as a single group (Figure 5a). This group includes 200 fissures that have a largely S-ward (43\%), NE-ward (23\%) and W-ward $(20.5 \%)$ direction, which is mainly along the rifts. These fissures are in general poorly known, and they have been studied previously mainly through morpho-structural analysis using light detection and ranging (LIDAR) [Neri et al. 2008b, Favalli et al. 2009], detailed topographic mapping, and previous geological studies [Romano and Sturiale 1982]. Many of the fissures are only partly cropping out, as they have been, to lesser or greater degrees, buried by more recent eruptive products (in particular the fissures above 2,000 $\mathrm{m}$ asl) or by vegetation. For this reason, we consider only the frequency and the strike of these pre-1600 fissures, knowing that a significant part of their information might be lacking.

For the period between 1600-2010, we have identified a total of 76 eruptive events in the summit area, and 68 on the flanks. The first part of this period (1600-1669) was caracterized by a very high average output rate $\left(\sim 1.4 \mathrm{~m}^{3} \mathrm{~s}^{-1}\right)$ [Behncke and Neri 2003, Behncke et al. 2005], and in one occasion (in 1669) by a devasting eruption that partially destroyed the town of Catania and numerous villages located on the S flank of the volcano [Crisci et al. 2003]. For a century after 1669 , the eruption frequency dramatically dropped, and then it started to rise again in the second half of the $18^{\text {th }}$ century. A clear increase in the eruption frequency and output rate has occurred since $1950\left(0.71 \mathrm{~m}^{3} \mathrm{~s}^{-1}\right.$ on the average output in the period 1050-1970), and especially since the late $1970 \mathrm{~s}\left(1.26 \mathrm{~m}^{3} \mathrm{~s}^{-1}\right.$, one eruption every 1.5 years on average; see also Figure 4). Analysing the dataset by centuries, we observe that seven summit and 11 flank events occurred during the $17^{\text {th }}$ century, and 14 summit and eight flank events during the $18^{\text {th }}$ century (Figure $5 \mathrm{~b}$ ); 13 summit and flank events occurred during the $19^{\text {th }}$ century (Figure $5 \mathrm{c}$ ), and 32 summit and 27 flank events occurred during the $20^{\text {th }}$ century (Figure $5 \mathrm{~d}$ ). During the first decade of the $21^{\text {st }}$ century, we must add other summit events (in 2000-2001, 2006, 2007-2008), three summit eruptions which occasionally fed eruptive fissures close to the summit area $(2006,2007)$, and six flank events between 2001 and 2010 (Figure 5).

For the 1900-2010 period, the dataset allows us to construct a detailed chronology and structural description of the eruptive fissures, which is shown in Table 1 . The total time that Etna was in eruption is $\sim 13,300$ days ( $36 \%$ of the analyzed time); 71 eruptions (31 of which were summit eruptions) produced 81 eruptive fissures on the volcano flanks. Indeed, in some cases, the same eruption produced two or more eruptive systems with different orientations, such as the 2001 and 2002-2003 eruptions. These both consisted of a central-lateral event located near the SE Crater, in the Valle del Leone (in 2001), and on the NE Rift (20022003), as well as eccentric events on the S flank [Neri et al. 2004]. The independence of the eccentric portions of these eruptions from the central conduit was suggested by the distribution of the seismic activity [Acocella et al. 2003, Neri et al. 2005, Walter et al. 2005], by the composition of the eruptive products [Corsaro et al. 2007], and by the geometry and timing of the opening of the eruptive fractures [Billi et al. 2003, Lanzafame et al. 2003]. With the exception of the twin 1974 eccentric eruptions in the W Rift zone [Corsaro et al. 2009], the other flank eruptive systems were equally distributed in the N (19 fissures) and S (19) sectors.

The flank eruptions lasted between less than one day (e.g., 1908 and 1942) and 473 days (in 1991-1993), with a median of 23 days. The velocity of propagation of the fractures was up to $\sim 1 \mathrm{~ms}^{-1}$ (during the initial phase of the fracturing sequence), similar to that inferred for Iceland [Gudmundsson 1995], with mean values between $0.26 \mathrm{~ms}^{-1}$ and $0.01 \mathrm{~ms}^{-1}$; the time required to develop a steady deformation pattern is of the order of a few tens of hours (median, $20 \mathrm{~h}$ ), up to a few hundreds of hours (Tables 1 and 2). In the $\mathrm{N}$ sector, the eruptions did not last quite as long

\begin{tabular}{|c|c|c|c|c|c|c|c|c|c|c|c|c|c|c|}
\hline & & & & & & vents & & & & ava flow & & tephra & & \\
\hline & $\begin{array}{l}\text { ype of eruption } \\
\text { and sectors }\end{array}$ & $\begin{array}{l}\text { duration } \\
\text { (days) }\end{array}$ & $\begin{array}{l}\max \\
\text { altitude } \\
\text { (m a.s.l.) }\end{array}$ & $\begin{array}{c}\min \\
\text { altitude } \\
\text { (m a.s.l.) }\end{array}$ & $\begin{array}{l}\text { length } \\
\text { (m) }\end{array}$ & $\begin{array}{l}\text { duration of } \\
\text { propagation } \\
\text { (h) }\end{array}$ & $\begin{array}{c}\text { mean speed } \\
\text { of propagation } \\
(\mathrm{m} / \mathrm{s})\end{array}$ & $\begin{array}{l}\text { width of the } \\
\text { fracture field } \\
\text { (m) }\end{array}$ & $\begin{array}{l}\max \\
\text { length } \\
(\mathrm{km})\end{array}$ & $\begin{array}{c}\text { area } \\
\left(10^{6} \mathrm{~m}^{2}\right)\end{array}$ & $\begin{array}{l}\text { volume } \\
\left(10^{6} \mathrm{~m}^{3}\right)\end{array}$ & $\begin{array}{l}\text { volume } \\
\left(10^{6} \mathrm{~m}^{3}\right)\end{array}$ & $\begin{array}{c}\text { total } \\
\text { volume } \\
\left(10^{6} \mathrm{~m}^{3}\right)\end{array}$ & $\begin{array}{l}\text { eruption } \\
\text { rate } \\
\left(\mathrm{m}^{3} \mathrm{~s}^{-1}\right)\end{array}$ \\
\hline & all eruptions & 30.5 & & & & & & & 4 & 2 & 10 & 1 & 11 & 5.7 \\
\hline & mmit eruption & 77 & & & & & & & 3 & 1.3 & 4.8 & 3.7 & 6.9 & 4.9 \\
\hline$\cong$ & all & 23 & 3030 & 2375 & 2338 & 20 & 0.05 & 300 & 4.6 & 2.3 & 18.5 & 0.5 & 22.6 & 5.7 \\
\hline 苛 & N sector & 21 & 3010 & 2200 & 3825 & 22.8 & 0.053 & 450 & 6.1 & 3 & 18 & 1 & 21 & 7 \\
\hline$\ddot{\tilde{a}}$ & $S$ sector & 30 & 3050 & 2420 & 1840 & 15 & 0.04 & 150 & 4.1 & 2 & 19 & 0 & 24 & 5.8 \\
\hline 世 & W sector & 18 & 1660 & & & & & & 1.4 & 0.3 & 2.3 & 1.6 & 3.8 & 2 \\
\hline
\end{tabular}

Note: a.s.l. - above sea level.

Table 2. Median volcanological and structural parameters of Etna eruptions, displayed for all of the post-1900 eruptions, summit and flank eruptions, and for each of the N, S and W sectors. 
(median, 21 days), developed faster $\left(0.053 \mathrm{~ms}^{-1}\right)$, and produced longer $(3,825 \mathrm{~m})$ fissures. In the $\mathrm{S}$ sector, the eruptions were frequently longer in duration (median, 30 days), but they were characterized by more slowly propagating $\left(0.04 \mathrm{~ms}^{-1}\right)$ and shorter $(1,840 \mathrm{~m})$ fissures. Conversely, the summit eruptions were usually longer (median, 77 day) and had moderate eruption rates $\left(<5 \mathrm{~m}^{3} \mathrm{~s}^{-1}\right)$, although they were also frequently characterized by violent paroxysms that lasted for a few tens of minutes at very high effusive rates $\left(50->200 \mathrm{~m}^{3} \mathrm{~s}^{-1}\right)$ [see Behncke et al. 2005, 2006].

Several correlations have been derived from the data given in Table 1, and these are shown in Figure 6. There is a positive correlation between the volume of the erupted products and the duration of the eruptions (Figure 6a), in a similar fashion to the positive correlation between the erupted volumes and the length of the lava flows (Figure 6i), as well as the area covered by the lava flows (Figure 61). In some cases, there is a moderate correlation $\left(\mathrm{R}^{2}=0.56\right)$ between the length of the eruptive fissures and the maximum width of the fracture field (Figure $6 \mathrm{~b}$ ). Moreover, the longer the eruptive fissures, the longer the related lava flows are (Figure $6 \mathrm{c}$ ), and the higher the eruption rates are (Figure $6 \mathrm{~g}$ ). It is also evident that higher eruption rates characterize shorter eruptions (Figure 6d).

Correlations between the velocities of the propagation of the fissures and the remaining parameters considered in Table 1 appear less-well defined. Only the erupted volumes can somehow be correlated to this velocity, which suggests that the largest eruptions were produced by rapid propagation of the eruptive fissures.

\section{Discussion}

The eruptions over the last century show a common trend of development: initially Strombolian activity from the summit craters that lasts for several months and is often punctuated by brief, violent paroxysms; this activity precedes, and occasionally accompanies, the flank eruptions. These last occur through fractures associated with the lateral propagation of radial dikes from the summit of the volcano (i.e. the Central Craters). Thus, very often, radial dikes transfer magma from the central conduit (and from the Summit Craters) towards the lower portions of the volcano, along sub-horizontal flow paths [Murray and Pullen 1984,
Ferrari et al. 1991, Bousquet and Lanzafame 2001, Acocella et al. 2009]. Summit activity typically ends shortly after the beginning of such flank eruptions.

During dike propagation, the magmatic activity and the related eruptive fracture field migrate downslope. This migration generally lasts less than two days, at speeds of the order of $\sim 0.1-1 \mathrm{~ms}^{-1}$ (except in very rare cases like in 2004, when the propagation lasted $\sim 6$ days) [Neri and Acocella 2006], after which the fracture field is complete and the eruptive vents are stabilized in the lower portion. The fracture field consists of tension fractures and normal faults, with vertical displacements of $<2-3 \mathrm{~m}$; the cumulative extension along each fissure, as measured directly in the field, is usually $<6 \mathrm{~m}$. The faults are typically arranged in grabens, with a width between $10 \mathrm{~m}$ and 1,400 $\mathrm{m}$ [Acocella and Neri 2003, Billi et al. 2003, Neri and Acocella 2006]. The formation of tension fractures or normal faults at the surface usually depends upon the depth of the dike [Bousquet and Lanzafame 2001]. A shallow dike, under lower lithostatic pressures, can induce tension fractures and minor grabens (up to $\sim 500 \mathrm{~m}$ wide). Conversely, a deeper dike, at higher confinement pressures, can form shear fractures [Pollard et al. 1983], and thus grabens at the surface, which might become strongly asymmetric if the fractures propagate along dip scarps (as happened in the Valle del Leone area during the 2001 eruption) [Billi et al. 2003].

Above $2,000 \mathrm{~m}$ asl, the eruptive fissures have a scattered orientation, although they also show a preferential N-S trend, especially close to the summit crater area. At lower altitudes, so below 2,000 $\mathrm{m}$ asl, the fissures mainly propagate towards the NE, S-SE and W, which coincides with the rift zones of the volcano (Figure 1). This structural arrangement is more evident when looking at the distribution of the older eruptive fissures (pre-1600; Figure 5a), which were widely concentrated along the rift zones and (partly) aligned accordingly to several faults (Figure 1).

The fissures propagating towards the NE are mainly concentrated in the homonymous NE Rift, which consists a network of N-to-NE-striking, closely spaced, subparallel eruptive fractures that can be traced down to the Mount Rosso area, at 1,500 m asl. The width of the Rift is $0.5 \mathrm{~km}$, and its length exceeds $7 \mathrm{~km}$ (Figure 1). A secondary zone that is affected by less numerous, but concentrated, NE-ENE

Figure 6 (next page). Comparisons of different parameters for eruptions and eruptive fissures, updated and extended from Acocella and Neri [2003] and Behncke et al. [2005]. (a) Eruption volume versus duration, showing generally higher lava volumes for longer eruptions, although there are wide variations, especially for eruptions lasting $<1$ yr. (b) Fracture field width versus length, indicating that longer fracture fields tend to also be wider. (c) Length of the lava flow-field versus length of the eruptive fissure system, showing that longer fissures produce longer flows. (d) Eruption duration versus mean eruption rate, where it is clear that shorter eruptions have higher mean eruption rates. (e) Eruptive fracture length versus altitude, indicating that fissures tend to be longer on the lower flanks. (f) Mean eruption rate versus elevation of the lowest vents, showing that eruption rates tend to be higher from low-lying vents and fissures. (g) Length of eruptive fissure systems versus eruption rates, where a broadly positive correlation is evident. (h) Eruptive fissure propagation speed versus total erupted volume, indicating that larger volumes are produced from fast-propagating fissure systems. (i) Maximum length of the lava flow-field versus total erupted volume, showing that in most cases longer lava flow-fields are also more voluminous. (j) Lava flow-field area versus total volume are clearly positively correlated. 

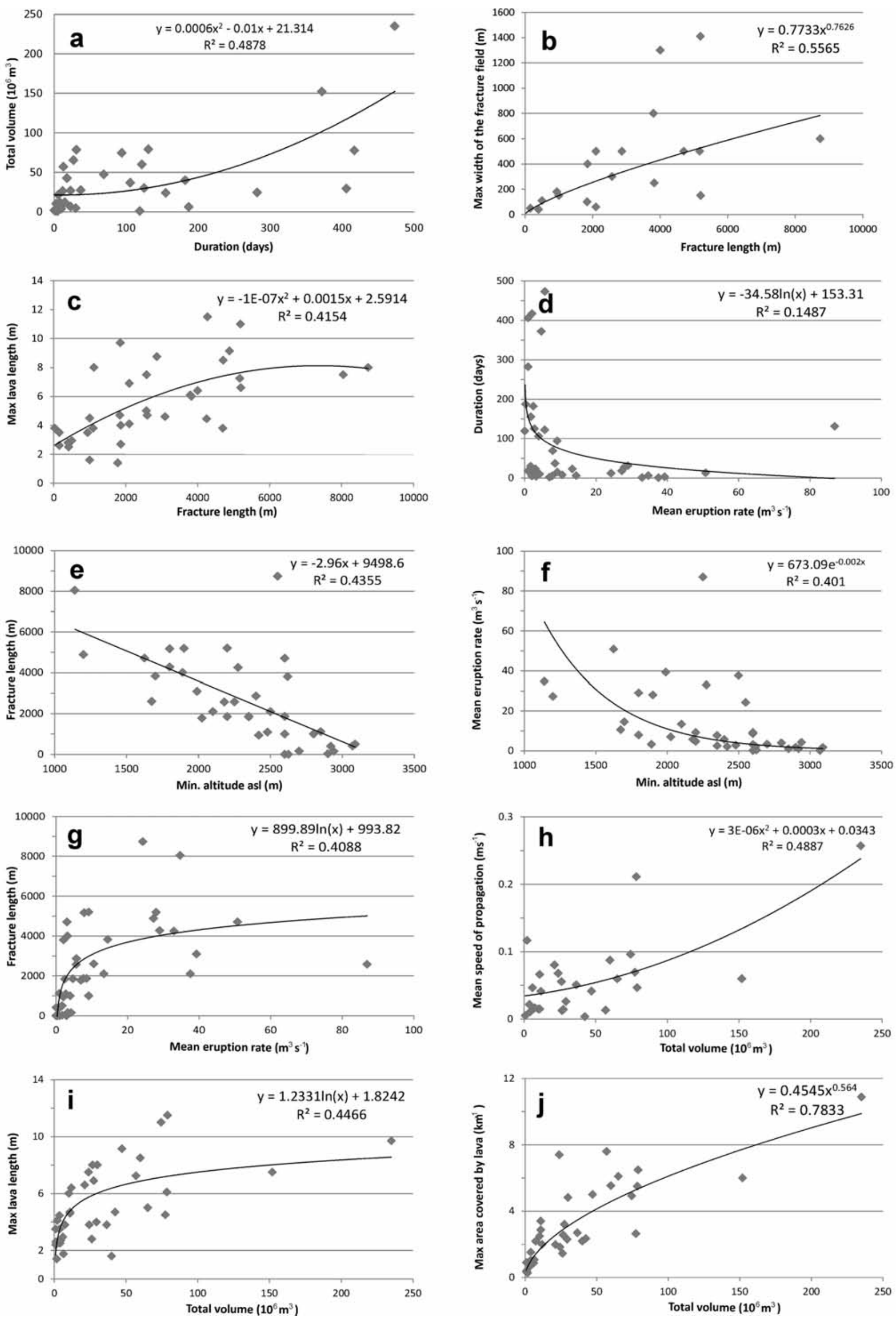

Figure 6 (see previous page). 
aligned eruptive fissures is located a couple of kilometers to the $\mathrm{E}$ of the NE Rift, where the vents reach minimum altitudes of about $850 \mathrm{~m}$ asl (Figure 1). All these vents are associated with fractures with left lateral components of motion [Neri et al. 2004]. The NE-ENE aligned fissures represent a secondary rift zone, which indicates a buried laterally-propagated dike system that filled a buried graben. The magmatic and tectonic activities of this secondary rift zone can be related to the development of an E-dipping rotational detachment that is confined by the NE Rift and the Pernicana Fault [Ruch et al. 2010].

The $S$ sector of Etna hosts the $S$ Rift, which occupies a wider $(\sim 10 \mathrm{~km})$ and longer $(>16 \mathrm{~km})$ area, with respect to the NE Rift. Here, the eruptive vents propagate mainly to the $S$ (above $1,300 \mathrm{~m}$ asl; see rose diagram in Figure $5 \mathrm{e}$ ) and to the SE (below 1,300 $\mathrm{m}$ ), and they are associated with fractures with right-lateral motion [Acocella and Neri 2003]. These latter often strike parallel (or close to parallel) to several faults that cut the lower SE flank of the volcano (Figure 1, TF and TMF). These faults are frequently invoked as margins of blocks collapsing in slow motion towards the Ionian Sea [Falsaperla et al. 2010, Solaro et al. 2010, and references therein], which suggests the existence of a link between these eruptive fractures and the local tectonic framework.

More in general, the kinematics characterizing the eruptive fractures cropping out on the $\mathrm{N}$ and $\mathrm{S}$ flanks is consistent with that of the Pernicana fault system (to the NE), the Tardaria-Mascalucia fault system (to the SE), and the Ragalna fault system (to the SW), confining the mobile E and S sectors of the volcano (Figure 1) [Rust et al. 2005, Solaro et al. 2010, and references therein].

These observations suggest a lack of shallow magma storage beneath the NE and S Rifts [McGuire and Pullen 1989]. Moreover, most dykes that crop out in the Valle del Bove (Figure 1) show sub-horizontal flow directions [Ferrari et al. 1991, Acocella et al. 2009]. This leads to the proposal of a similar lateral mechanism of magma emplacement during the last approximately $45 \mathrm{ka}$, the age of the current main feeding system [Branca et al. 2004].

Etnean rifts appear to be influenced by the regional tectonic stress field. Kieffer [1985] suggested that the rifts are the W boundary of a fault system that separates the Sicilian continental crust and the Ionian oceanic crust. McGuire and Pullen [1989] argued that only the NE Rift is related to the regional stress field, because it is parallel to the maximum compressive stress. Borgia et al. [1992] and Lo Giudice and Rasà [1992] interpreted the NE and S Rifts as disjunction zones that separate sectors of the volcano that are characterised by different kinematics. In this context, the magma fills the rift zones because of the collapse of the portion of the volcano that is delimited by the Pernicana fault system to the $\mathrm{N}$, and by the Ragalna fault system to the SW (Figure 1).

Even though the NE and S Rifts may have a link with the spreading phenomena affecting the $\mathrm{E}$ to $\mathrm{S}$ flanks of Etna [see Acocella et al. 2003], the role of the W Rift remains unclear. The seismicity of this area is often deeper $(>5-10$ $\mathrm{km}$ ) if compared to that of the E flank [Patanè et al. 2002, Mattia et al. 2007]. In several cases, earthquakes in this sector heralded and marked the rise of magmatic intrusions, as in 1974 [Corsaro et al. 2009], 1991 [Ferrucci and Patanè 1993], and 1998-1999 [Bonaccorso and Patanè 2001, Patanè et al. 2003]. This suggests that for the $\mathrm{W}$ flank the possible existence of a storage area under the W Rift, or a preferential path used by magmas to reach the surface.

As noted by several studies [Wadge et al. 1975, Behncke and Neri 2003, Allard et al. 2006], the activity of Mount Etna (in terms of output rate and flank eruption frequency) undergoes significant fluctuations over time. These fluctuations do not occur in a random manner, but represent various stages of the eruptive cycles on a scale of decades and centuries [Behncke and Neri 2003]. As shown in Section 2, short-term cycles last 20-40 years and consist of three distinct phases: (I) a period of rest; (II) a period of summit activity; and (III) a series of flank eruptions that occur at intervals of a few years, with frequent summit activity during the intervals between the flank eruptions.

The timing, frequency, and clustering of the flank eruptions appear to be related to the instability of the $E$ to $S$ sector of Etna, which is expressed in episodic slippage of portions of the unstable sector. During such events, displacement on a scale varying from centimeters to meters can affect one or more distinct slide blocks [Solaro et al. 2010, and reference therein], and this is commonly accompanied by shallow seismicity along the faults confining the slide blocks [Acocella et al. 2003, Neri et al. 2005, Walter et al. 2005]. In general, the longer the eruptive fracture systems, the faster and wider the displacement of the sliding blocks is [Neri et al. 2004]. This means that the most dangerous eruptions (characterized by vents at lower elevation, feeding large lava volumes at a high rate; see Figure $6 \mathrm{c}, \mathrm{e}, \mathrm{g}, \mathrm{i})$ appear to be related to periods of high dynamics of flank movement.

We thus envisage the following scenario for a feedback mechanism between magma accumulation, flank instability and slippage, and eruptions: (a) magma accumulation occurs about 5-10 km below the sea level [Murru et al 1999, Palano et al. 2009], just below the depth of the presumed basal décollement plane of the unstable, slipping flank sector [Bonforte et al. 2008, Ruch et al. 2010]; this causes inflation of the volcanic edifice; (b) swelling of the volcanic edifice leads to destabilization (at first slow spreading and fault creep, followed by instantaneous flank slip accompanied by shallow seismicity) of the unbuttressed $\mathrm{E}$ to $\mathrm{S}$ sector of the volcano; (c) extension at the head of the active slide block(s) facilitates magma migration from the central conduit system and/ or shallow eccentric reservoirs into radial flank fracture systems (and into the rift zones), usually leading to lateral 
flank eruptions.

The observed patterns over the recent eruptive history of Etna appear therefore to be controlled by the shorterterm cycles, which might be involved in an effective interaction with the shallow structure of the volcano and its unstable portions.

\section{Conclusions}

In the present study, we have investigated the structural elements of eruptions since 1900 at Etna, with the integration of the database with the main parameters (frequency and strike) of older eruptive fissures (up to approximately $2 \mathrm{ka} \mathrm{BP}$ ). This approach has allowed us to improve our understanding of the dynamics of the summit and flank eruptions, with an analysis of the possible links with the structural instability that affects the volcano flanks.

At high altitudes (above 2,000 $\mathrm{m}$ asl), the eruptive fissures have a scattered orientation, while at lower altitudes, they mainly propagate towards NE, S-SE and W, marking three rift zones. Over the last 110 years, which represents our most complete volcano-tectonic dataset, the flank eruptions lasted a median of 23 days, with eruption rates $>5.7 \mathrm{~m}^{3} \mathrm{~s}^{-1}$. The mean interval required to develop a steady deformation pattern is $20 \mathrm{~h}$, with fissures that propagate at an average speed of $0.05 \mathrm{~ms}^{-1}$. In the $\mathrm{N}$ sector, the eruptive fissures developed slightly quicker $\left(0.053 \mathrm{~ms}^{-1}\right)$ and grew for longer $(3,825 \mathrm{~m})$, with respect to the fissures that have affected the $\mathrm{S}$ sector (velocity, 0.04 ; length $1,840 \mathrm{~m}$ ). Conversely, the summit eruptions were usually longer (77 days), with lower eruption rates $\left(1-2 \mathrm{~m}^{3} \mathrm{~s}^{-1}\right)$, even if they were occasionally characterized by short-lived violent paroxysms (eruption rate, $>50-100 \mathrm{~m}^{3} \mathrm{~s}^{-1}$ ).

Longer eruptive fractures tend to produce higher eruptive rates, greater lava volumes, and longer lava flows. The longest eruptive fractures, moreover, develop wider fracture fields.

The observed patterns in the recent eruptive history of Etna also confirm the existence of a feedback mechanism between magma accumulation, flank instability and eruptions, which consists of: (a) magma accumulation at shallow crustal levels $(5-10 \mathrm{~km}$ bsl); (b) swelling of the volcanic edifice, leading to the destabilization of the unbuttressed sectors of the volcano; and (c) extension at the head of the active sliding block(s), which facilitates magma migration from the central conduit system into radial flank fracture systems, thus feeding flank eruptions.

The most dangerous eruptions for human activities (characterized by vents at lower elevation, i.e. close to inhabited areas, feeding large lava volumes at high rates) appear to be related to periods of intense dynamics of flank movements, such as in the 1980 s and at the beginning of the $21^{\text {st }}$ century.

In this framework, continuous monitoring of the volcano-tectonic structures that affect the Etna volcano is an essential tool to better define the relationships between regional tectonics, flank dynamics and flank volcanic activity, and thus to better understand the modalities (duration, extrusion rates) of flank eruptions, which represent the most dangerous type of eruptive activity at Etna.

Acknowledgements. This work was sponsored by the Italian National Civil Defence Department and INGV (Istituto Nazionale di Geofisica e Vulcanologia), project V3-LAVA (RU01-Team 01C). The manuscript benefited from the useful reviews by S. Calvari and R. Sulpizio.

\section{References}

Allard, P., B. Behncke, S. D'Amico, M. Neri and S Gambino (2006). Mount Etna 1993-2005: Anatomy of an evolving eruptive cycle, Earth-Sci. Rev., 78, 85-114; doi: 10.1016/j. earscirev.2006.04.002.

Acocella, V. and M. Neri (2003). What makes flank eruptions?: The 2001 Etna eruption and the possible triggering mechanisms, B. Volcanol., 65, 517-529; doi: 10.1007/ s00445003-0280-3.

Acocella, V., B. Behncke, M. Neri and S. D'Amico (2003). Link between major flank slip and eruptions at Mt. Etna (Italy), Geophys. Res. Lett., 30, 2286; doi: 10.1029/2003GL 018642.

Acocella, V. and M. Neri (2009). Dike propagation in volcanic edifices: overview and possible developments, Tectonophysics, 471, 67-77; doi: 10.1016/j.tecto.2008.10.002.

Acocella, V., M. Neri and R. Sulpizio (2009). Dike propagation within active central volcanic edifices: constraints from Somma-Vesuvius, Etna and analogue models, B. Volcanol., 71, 219-223; doi: 10.1007/s00445-008-0258-2.

Adams, N.K., S.L. de Silva, S. Self, G. Salas, S. Schubring, J.L. Parmenter and K. Arbesman (2001). The physical volcanology of the 1600 eruption of Huaynaputina, southern Peru, B. Volcanol., 62, 493-518.

Behncke, B. and M. Neri (2003). Cycles and trends in the recent eruptive behaviour of Mount Etna (Italy), Can. J. Earth Sci., 40,1405-1411; doi: 10.1139/E03-052.

Behncke, B., M. Neri and A. Nagay (2005). Lava flow hazard at Mount Etna (Italy): New data from a GIS-based study, In: Kinematics and Dynamics of Lava Flows, edited by M. Manga and G. Ventura, Spec. Pap. Geol. Soc. Am., 396-13, 187-205; doi: 10.1130/0-8137-2396-5.189.

Behncke, B., M. Neri, E. Pecora and V. Zanon (2006). The exceptional activity and growth of the Southeast Crater, Mount Etna (Italy), between 1996 and 2001, B. Volcanol., 69, 149-173; doi: 10.1007/ s00445-006-0061-x.

Billi, A., V. Acocella, R. Funiciello, G. Giordano, G. Lanzafame and M. Neri (2003). Mechanisms for ground-surface fracturing and incipient slope failure associated to the July-August 2001 eruption of Mt. Etna, Italy: analysis of ephemeral field data, J. Volcanol. Geoth. Res., 122, 281294; doi:10.1016/S0377-0273(02)00507-3.

Bonaccorso, A. and D. Patanè (2001). Shear response to an 
intrusive episode at Mt. Etna volcano (January 1998) inferred through seismic and tilt data, Tectonophysics, 334, 61-75; doi: 10.1016/S0040-1951(01)00056-7.

Bonforte, A., A. Bonaccorso, F. Guglielmino, M. Palano and G. Puglisi (2008). Feeding system and magma storage beneath Mt. Etna, as revealed by recent inflation/deflation cycles, J. Geophys. Res., 113, B05406; doi: 10.1029/2007JB005334.

Borgia, A., L. Ferrari and G. Pasquarè (1992). Importance of gravitational spreading in the tectonic and volcanic evolution of Mt. Etna, Nature, 357, 231-235.

Bousquet, J.C. and G. Lanzafame (1986). Déformations compressives quaternaires au bord sud de l'Etna, C. R. Acad. Sc. Paris, 303, 235-240.

Bousquet, J.C. and G. Lanzafame (2001). Nouvelle interprétation des fractures des éruptions latérales de l'Etna: conséquences pour son cadre tectonique, B. Soc. Géol. Fr., 172, 455-467.

Branca, S., M. Coltelli and G. Groppelli (2004). Geological evolution of Etna volcano, In: Etna Volcano Laboratory, Geophys. Monogr. Ser., vol. 143, edited by A. Bonaccorso et al., AGU, Washington, D.C., 49-63.

Branca, S. and P. Del Carlo (2005). Types of eruptions of Etna volcano AD 1670-2003: implications for short-term eruptive behaviour, B. Volcanol., 67, 732-742. doi: 10.1007/ s00445-005-0412-z.

Corazzato, C. and A. Tibaldi (2006). Fracture control on type, morphology and distribution of parasitic volcanic cones: an example from Mt. Etna, Italy, J. Volcanol. Geoth. Res., 158, 177-194; doi: 10.1016/j.jvolgeores.2006.04.018.

Corsaro, R., M. Neri and M. Pompilio (2002). Paleo-environmental and volcano-tectonic evolution of the southeastern flank of Mt. Etna during the last $225 \mathrm{ka}$ inferred from volcanic succession of the "Timpe», Acireale, Sicily, J. Volcanol. Geoth. Res., 113, 289-306; doi: 10.1016/S03770273(01)00262-1.

Corsaro, R.A., L. Miraglia and M. Pompilio (2007). Petrologic evidence of a complex plumbing system feeding the JulyAugust 2001 eruption of Mt. Etna, Sicily, Italy, B. Volcanol., 69, 401-421.

Corsaro, R.A., N. Métrich, P. Allard, D. Andronico, L. Miraglia and C. Fourmentraux (2009). The 1974 flank eruption of Mount Etna: An archetype for deep dike-fed eruptions at basaltic volcanoes and a milestone in Etna's recent history., J. Geophys. Res., 114, B07204; doi: 10.1029/ 2008JB006013.

Crisci, G.M., S. Gregorio, R. Rongo, M. Scarpelli, W. Spataro and S. Calvari (2003). Revisiting the 1669 Etnean eruptive crisis using a cellular automata model and implications for volcanic hazard in the Catania area, J. Volcanol. Geoth. Res., 123, 211-230; doi: 10.1016/S0377-0273(03)00037-4.

Crisci, G.M., M.V. Avolio, B. Behncke, D. D'Ambrosio, S. Di Gregorio, V. Lupiano, M. Neri, R. Rongo and W. Spataro (2010). Predicting the impact of lava flows at Mount Etna,
J. Geophys. Res., 115, B04203; doi: 10.1029/2009JB006431. Cristofolini, R., F. Lentini, G. Patanè and R. Rasà (1979). Integrazione di dati geologici, geofisici, e metrologici per la stesura di un profilo crostale in corrispondenza dell'Etna, B. Soc. Geol. Ital., 98, 239-247.

Cronin, S.J., M. Bebbington and C.D. Lai (2001). A probabilistic assessment of eruption recurrence of Taveuni volcano, Fiji, B. Volcanol., 63, 274-288.

Falsaperla, S., F. Cara, A. Rovelli, M. Neri, B. Behncke and V. Acocella (2010), Effects of the 1989 fracture system in the dynamics of the upper SE flank of Etna revealed by volcanic tremor data: the missing link?, J. Geophys. Res., 115, B11306; doi: 10.1029/2010JB007529.

Favalli, M., D. Karátson, F. Mazzarini, M.T. Pareschi and E. Boschi (2009). Morphometry of scoria cones located on a volcano flank: a case study from Mt. Etna volcano (Italy), based on high-resolution LiDAR data, J. Volcanol. Geoth. Res., 186, 320-330; doi: 10.1016/j.jvolgeores.2009.07.011.

Ferrari, L., V.H. Garduño and M. Neri (1991). I dicchi della valle del Bove, Etna: un metodo per stimare le dilatazioni di un apparato vulcanico, Mem. Soc. Geol. Ital., 47, 495-508.

Ferrucci, F. and D. Patanè (1993). Seismic activity accompanying the outbreak of the 1991-1993 eruption of Mt Etna (Italy), J. Volcanol. Geoth. Res., 57, 125-135.

Geshi, N., T. Shimano, T. Chiba and S. Nakada (2002). Caldera collapse during the 2000 eruption of Miyakejima volcano, Japan, B. Volcanol., 64, 55-68.

Geshi, N., S. Kusumoto and A. Gudmundsson (2010). Geometric difference between non-feeder and feeder dikes, Geology, 38, 195-198; doi: 10.1130/G30350.1.

Guest, J.E. and J.B. Murray (1979). An analysis of hazard from Mount Etna volcano, J. Geol. Soc. London, 136, 347-354.

Gudmundsson, A. (1987). Lateral magma flow, caldera collapse and a mechanism of large eruptions in Iceland, J. Volcanol. Geoth. Res., 34, 65-78.

Gudmundsson, A. (1995). Infrastructure and mechanics of volcanic systems in Iceland, J. Volcanol. Geoth. Res., 64, $1-22$.

Gudmundsson, A. (1998). Magma chambers modeled as cavities explain the formation of rift zone central volcanoes and their eruption and intrusion statistics, J. Geophys. Res., 103, 7401-7412.

Holcomb, R.T. (1987). Eruptive history and long-term behaviour of Kilauea volcano, USGS Prof. Pap. 1350, 261-350.

Jonsson, S., H. Zebker, P. Cervelli, P. Segall, H. Garbeil, P. Mouginis-Mark and S. Rowland (1999). A shallow-dipping dike fed the 1995 flank eruption at Fernandina volcano, Galapagos, observed by satellite radar interferometry, Geophys. Res. Lett., 26, 1077-1080.

Kemmerling, G.L.L. (1922). De G. Sěmeroe, de G. Bråmå en de G. Lamongan in het begin van 1920, Vulkanologische Mededelingen, 4, 40 pp. 
Kieffer, G. (1985). Évolution structurale et dynamique d'un grand volcan polygénique: stade d'édification et activité actuelle de l'Etna, $\mathrm{PhD}$ thesis, Univ Clermont-Ferrand II, $497 \mathrm{pp}$.

Lanzafame, G., A. Leonardi, M. Neri and D. Rust (1997). Late overthrust of the Appenine-Maghrebian Chain at the NE periphery of Mt. Etna, Italy, C.R. Acad. Sc. Paris, 324, 325-332.

Lanzafame, G., M. Neri, V. Acocella, A. Billi, R. Funiciello and G. Giordano (2003). July-August 2001 Etna eruption: deformative pattern and its significance, J. Geol. Soc. London, 160, 531-544; doi: 10.1144/0016-764902-151.

Lentini, F. (1982), The geology of the Mt. Etna basement, Mem. Soc. Geol. It., 23, 7-25.

Lockwood, J.P., J.J. Dvorak, T.T. English, R.Y. Koyanagi, A.T. Okamura, M.L. Summers and W.R. Tanigawa (1987). Mauna Loa 1974-1984. A decade of intrusive and extrusive activity, USGS Prof .Pap. 1350, 537-570.

Lo Giudice, E. and R. Rasà (1992). Very shallow earthquakes and brittle deformation in active volcanic areas. The Etnean region as an example, Tectonophysics, 202, 257-268.

Mattia, M., D. Patanè, M. Aloisi and M. Amore (2007). Faulting on the western flank of Mt Etna and magma intrusions in the shallow crust, Terra Nova, 19, 89-94; doi: 10.1111/j.1365-3121.2006.00724.x.

McClelland, L., T. Simkin, M. Summers, E. Nielsen and T.C. Stein (1989). Global volcanism, 1975-1985, Prentice Hall, $657 \mathrm{pp}$.

McGuire, W.J. and A.D. Pullen (1989). Location and orientation of eruptive fissures and feeder dykes at Mount Etna; influence of gravitational and regional tectonic stress regimes, J. Volcanol. Geoth. Res., 38, 325-344; doi: 10.1016/0377-0273(89)90046-2.

Monaco, C. and L. Tortorici (2000). Active faulting in the Calabrian arc and eastern Sicily, J. Geodyn., 29, 407-424.

Murray, J.B. and A.D. Pullen (1984). Three dimensional model of feeder conduit of the 1983 eruption of Mount Etna volcano, from ground deformation measurements, B. Volcanol., 47, 1145-1163.

Murru, M., C. Montuori, M. Wyss and E. Privitera (1999). The locations of magma chambers at Mt. Etna, Italy, mapped by b-values, Geophys. Res. Lett., 26, 2553-2556.

Neri, M., V. Acocella and B. Behncke (2004). The role of the Pernicana fault system in the spreading of Mt. Etna (Italy) during the 2002-2003 eruption, B. Volcanol., 66, 417-430; doi: $10.1007 /$ s00445-003-0322-x.

Neri, M., V. Acocella, B. Behncke, V. Maiolino, A. Ursino and R. Velardita (2005). Contrasting triggering mechanisms of the 2001 and 2002-2003 eruptions of Mount Etna (Italy), J. Volcanol. Geoth. Res., 144, 235-255; doi: 10.1016/j.jvolgeores.2004.11.025.

Neri, M. and V. Acocella (2006). The 2004-05 Etna eruption: implications for flank deformation and structural behav- iour of the volcano, J. Volcanol. Geoth. Res., 158, 195-206; doi: $10.1016 /$ j.jvolgeores.2006.04.022.

Neri, M., G. Lanzafame and V. Acocella (2008a). Dike emplacement and related hazard in volcanoes with sector collapse: the 2007 Stromboli eruption, J. Geol. Soc. London, 165, 883-886; doi: 10.1144/0016-76492008-002.

Neri, M., F. Mazzarini, S. Tarquini, M. Bisson, I. Isola, B. Behncke and M.T. Pareschi (2008b). The changing face of Mount Etna's summit area documented with LiDAR technology, Geophys. Res. Lett., 35, L09305; doi: 10.1029/ 2008GL033740.

Neri, M., F. Casu, V. Acocella, G. Solaro, S. Pepe, P. Berardino, E. Sansosti, T. Caltabiano, P. Lundgren and R. Lanari (2009). Deformation and eruptions at Mt. Etna (Italy): a lesson from 15 years of observations, Geophys. Res. Lett., 36, L02309; doi: 10.1029/2008GL036151.

Palano, M., S. Gresta and G. Puglisi (2009). Time-dependent deformation of the eastern flank of Mt. Etna: After-slip or viscoelastic relaxation?, Tectonophysics, 473, 300-311; doi: 10.1016/j.tecto.2009.02.047.

Patanè, D., C. Chiarabba, O. Cocina, P. De Gori, M. Moretti and E. Boschi (2002). Tomographic images and 3D earthquake locations of the seismic swarm preceding the 2001 Mt. Etna eruption: evidence for a dyke intrusion, Geophys. Res. Lett., 29, 1497; doi: 10.1029/2001GL014391.

Patanè, D., C. Chiarabba, P. De Gori and A. Bonaccorso (2003). Magma ascent and the pressurization of Mt. Etna's volcanic system, Science, 299, 2061-2063.

Peltier, A., V. Famin, P. Bachèlery, V. Cayol, Y. Fukushima and T. Staudacher (2008). Cyclic magma storage and transfers at Piton de La Fournaise volcano (La Réunion hotspot) inferred from deformation and geochemical data, J. Volcanol. Geoth. Res., 270, 180-188; doi: 10.1016/j.epsl. 2008.02.042.

Pollard, D.D., P.T. Delaney, W.A. Duffield, E.T. Endo and A.T. Okamura (1983). Surface deformation in volcanic rift zones, Tectonophysics, 94, 541-584.

Rittmann, A. (1973). Structure and evolution of Mount Etna, Phil. Trans. Roy. Soc., London, 274, A, 5-16.

Romano, R. and C. Sturiale (1982). The historical eruptions of Mt. Etna (volcanological data), Mem. Soc. Geol. It., 23, 27-48.

Rubin, A.M. and D.D. Pollard (1987). Origins of blade-like dikes in volcanic rift zones, USGS Prof. Pap. 1350, 14491470.

Ruch J., V. Acocella, F. Storti, M. Neri, S. Pepe, G. Solaro and E. Sansosti (2010). Detachment depth of an unstable volcano revealed by rollover deformation: an integrated approach at Mt. Etna, Geophys. Res. Lett., 37, L16304; doi: 10.1029/2010GL044131.

Rust, D., B. Behncke, M. Neri and A. Ciocanel (2005). Nested zones of instability in the Mount Etna volcanic edifice, Sicily, J. Volcanol. Geoth. Res., 144, 137-153; doi: 
10.1016/j.jvolgeores.2004.11.021.

Solaro, G., V. Acocella, S. Pepe, J. Ruch, M. Neri and E. Sansosti (2010). Anatomy of an unstable volcano through InSAR data: multiple processes affecting flank instability at Mt. Etna in 1994-2008, J. Geophys. Res., 115, B10405; doi: 10.1029/2009JB000820.

Sumner, J.M. (1998). Formation of clastogenic lava flows during fissure eruption and scoria collapse: the 1986 eruption of Izu-Oshima volcano, eastern Japan, B. Volcanol. 60, 195-212.

Tanguy, H. and G. Kieffer (1993). Les éruptions de l'Etna et leurs mécanismes, Mem. Soc. Geol. Fr., 163, 239-252.

Tanguy, J.-C., M. Le Goff, C. Principe, S. Arrighi, V. Chillemi, A. Paiotti, S. La Delfa and G. Patanè (2003). Archeomagnetic dating of Mediterranean volcanics of the last 2100 years: validity and limits, Earth Plan. Sci. Lett., 211, 111-124.

Tedesco, D., O. Vaselli, P. Papale, S.A. Carn, M. Voltaggio, G.M. Sawyer, J. Durieux, M. Kasereka, and F. Tassi (2007). January 2002 volcano-tectonic eruption of Nyiragongo volcano, Democratic Republic of Congo, J. Geophys. Res., 112, B09202; doi: 10.1029/2006JB004762.

Wadge, G., G.P.L. Walker and J.E. Guest (1975). The output of Etna volcano, Nature, 255, 385-387.

Walter, T.R., V. Acocella, M. Neri and F. Amelung (2005). Feedback processes between magmatism and E-flank movement at Mt. Etna (Italy) during the 2002-2003 eruption, J. Geophys. Res., 110, B10205; doi: 10.1029/2005JB00 3688.

\footnotetext{
${ }^{\star}$ Corresponding author: Marco Neri, Istituto Nazionale di Geofisica e Vulcanologia, Sezione di Catania, Catania, Italy; email: marco.neri@ct.ingv.it. 